\title{
Innovative methods of teaching English for specific purposes at higher educational institutions
}

\author{
Zablotska L., Meleshchenko V., Chernii L.* \\ Ternopil Volodymyr Hnatiuk National Pedagogical University, Ternopil, Ukraine
}

Received: $10.03 .2019 \quad$ Accepted: 20.09 .2019

\begin{abstract}
The article is devoted to the study of innovative methods of teaching English for specific purposes at higher educational institutions. In particular, the concept of "innovation in higher education" has been analyzed; the difference between the terms "educational innovations" and "pedagogical innovations" has been determined; the types of innovations and the ways of innovation activity implementation at higher institutions have been considered; the features of innovative methods have been determined and modern approaches to the classification of teaching methods of English language have been examined. The article also traces the distinctive features of traditional and innovative learning. It has been stated, that traditional education is based on the fact that a student has to memorize and then reproduce the scope of the information, which was suggested him by the teacher. This kind of learning is authoritarian by character from the side of the teacher, and the student acts as a passive recipient of knowledge. Modernization of education provide the use of effective innovative methods of education and upbringing. Studying English for specific purposes involves the formation of students' foreign language communication skills in the specialty, so, that they will be able to find the necessary information and share it with their foreign counterparts independently in their professional activity. The author of the given articles, relying on their own practical experience, noted that methods of teaching English language are constantly evolving and changing along with the changes of information technologies and modern society. The article offers useful Internet resources, programs, the most effective innovative methods of teaching English for specific purposes (problem-based method, case method, roleplay, synectics, brainstorming, gamificaton, etc.). The use of innovative teaching methods in higher education promotes students' creativity, active search and use of information, increases their learning motivation; their knowledge and skills, contributes to forming the willingness to solve problematic situations in their professional activity.
\end{abstract}

Key words: innovations, innovative methods, innovative teaching, English for specific purposes

\section{Інноваційні методи навчання англійської мови за професійним спрямуванням у закладах вищої освіти}

\author{
Заблоцька Л. М., Мелещенко В. О., Черній Л. В.
}

Тернопільський національний педагогічний університет імені Володимира Гнатюка, Тернопіль, Україна

\begin{abstract}
Анотація. Дана стаття присвячена вивченню інноваційних методів у процесі навчання іноземної мови за профресійним спрямуванням у вищих освітніх закладах. Зокрема аналізується поняття "інновація у вищій освіті", встановлено відмінності між термінами “освітні інновації" та "педагогічні інновації", розглянуто види інновацій та напрями їх впровадження у вишах, визначено характерні особливості інноваційних методів та ознайомлено із сучасними підходами щодо класифікації методів навчання англійської мови. У статті розглянуто характерні відмінності традиційного та інноваційного навчання й виявлено, що традиційна освіта ¡рунтується на запам'ятовуванні та відтворенні певного об'єму інформації, який подається студенту викладачем. Таке навчання має авторитарний характер з боку викладача, а студент виступає у ролі пасивного реципієнта знань. Модернізація освіти на сучасному етапі передбачає використання ефективних інноваційних методів навчання та виховання. Вивчення англійської мови за професійним спрямуванням сприяє формуванню іншомовних комунікативних навичок з фаху для того, щоб у майбутньому фахівці могли самостійно знаходити необхідну інформацію та обмінюватися нею із своїми зарубіжними колегами. Автори публікації, покладаючись на власний практичний досвід роботи, зазначили, що методи навчання англійської
\end{abstract}

Corresponding Author: Zablotska Liubov Mykhailivna. Tel. +38(098)584-40-94. E-mail: lubazab@ukr.net Ternopil Volodymyr Hnatiuk National Pedagogical University, Maksyma Kryvonosa street 2, Ternopil, Ukraine, 46027

відповідальний автор: Заблоцька Любов Михайлівна. +38(098)584-40-94. E-mail: lubazab@ukr.net Тернопільський національний педагогічний університет імені Володимира Гнатюка, вул. Максима Кривоноса, м. Тернопіль, Україна, 46027. 
мови постійно розвиваються й змінюються паралельно із зміною інформаційних технології й суспільства. У статті запропоновано корисні інтернет-ресурси, навчальні програми, виокремлено найбільш ефективні інноваційні методи навчання англійської мови за професійним спрямуванням (метод проблем, кейс метод, метод рольової гри, метод синектики, метод "мозкової атаки", гейміфікації та ін.). Використання інноваційних методів навчання у вишах сприяє розвитку у студентів творчого самовираження, здійсненню активного пошуку й використання інформації, підвищує їх мотивацію до навчання, а набуті ними знання, вміння та навички сприяють формуванню готовності вирішувати проблемні ситуації у професійній діяльності.

Ключові слова: інновації, інноваційні методи, інноваційне навчання, англійська мова за професійним спрямуванням

\title{
Инновационные методы обучения английскому языку для специальных целей в учреждениях высшего образования
}

\author{
Заблоцька Л. М., Мелещенко В. А., Черний Л.В. \\ Тернопольский национальный педагогический университет имени Владимира Гнатюка, Тернополь, Украина
}

\begin{abstract}
Аннотация. Данная статья посвящена изучению инновационных методов обучения иностранного языка для специальных целей в высших учебных заведениях. В частности анализируется понятие "инновация в высшем образовании", установлены различия между понятиями "образовательные инновации" и "педагогические инновации", рассмотрены виды инноваций и направления их внедрения в вузах, определены характерные особенности инновационных методов и проанализированы современные подходами к классификации методов обучения английского языка. В статье рассмотрены характерные отличия традиционного и инновационного обучения и обнаружено, что традиционное образование основано на запоминании и воспроизведении определенного объема информации. Такое обучение имеет авторитарный характер со стороны преподавателя, а студент выступает в роли пассивного реципиента знаний. Модернизация образования на современном этапе предусматривает использование эфффективных инновационных методов обучения и воспитания. Изучение английского языка для специальных целей способствует формирование иноязычных коммуникативных навыков по специальности для того, чтобы в будущем специалисты могли самостоятельно находить необходимую инфрормацию и обмениваться ею со своими зарубежными коллегами. Авторы публикации, полагаясь на собственный практический опыт работы, отметили, что методы обучения английского языка постоянно эволюционируют и меняются параллельно с изменением инфформационных технологий и общества. В статье предложен полезные интернет-ресурсы, учебные программы, выделены наиболее эффрективные инновационные методы обучения английскому языку по профеесиональному направлению (метод проблем, кейс метод, метод ролевой игры, метод синектики, метод "мозговой атаки", геймификация и др.). Использование инновационных методов обучения в вузах способствует развитию у студентов творческого самовыражения, способствует активному поиску и использованию инфрормации, повышает их мотивацию к обучению, а приобретенные ими знания, умения и навыки способствуют формированию готовности решать проблемные ситуации в профессиональной деятельности.

Ключевые слова: инновации, инновационные методы, инновационное обучение, английский язык по профессиональному направлению.
\end{abstract}

\section{Bcmyn}

Швидкий розвиток технічного прогресу, інформатизація, впровадження інноваційних та інформаційних технологій в усі сфери життя стали невід'ємними рисами сучасного суспільства. Величезна популярність телекомунікаційних технологій та Інтернету, новітніх мобільних ґаджетів, безперечно, впливає й на освітнє середовище й зумовлює переосмислення їх місця та ролі у навчальному процесі. Модернізація освіти, в основу якої покладено використання інноваційних методів навчання, $є$ на даному етапі одним із пріоритетних завдань. Адже сучасний світ ставить нові вимоги до усіх ланок суспільного життя, у тому числі й до професійної підготовки студентів.

Вивчення англійської мови за професійним спрямуванням передбачає фрормування іншомовної комунікативної компетенції з фаху з тим, щоб у майбутньому фахівці могли самостійно знаходити необхідну інформацію та обмінюватися нею із своїми зарубіжними колегами. Перед викладачем англійської мови стоїть завдання - створити оптимальні умови для практичного оволодіння англійською мовою. Учителями-практиками, викладачами та науковцями постійно здійснюються розвідки, ведуться пошуки нових методик, технологій, форм та методів навчання, які б ефективно та дієво впливали на формування іншомовної комунікативної компетенції учнів та студентів. Використання інноваційних методів та технологій навчання у сфері вищої професійної освіти, яка готує професійні та наукові кадри 
для всіх галузей промисловості та сфер життя людини, є одним із шляхів, що уможливлює оптимізування та модернізпацію процесу навчання.

Тому вважаємо, що порушена проблема про використання ефективних інноваційних методів навчання англійської мови за професійним спрямуванням $€$ актуальною для сьогодення, а вивчення, аналіз та поширення передового вітчизняного та зарубіжного науково-педагогічного досвіду у царині методики іншомовного навчання поліпшило б якість знань, умінь та навичок майбутніх фахівців.

Аналіз останніх досліджень і публікацій проблеми показав, що теоретичні положення процесу модернізації в освіті знайшли обґрунтування у працях В.Бебика, Я. Болюбаша, Н. Дворнікової, В. Журавського та інші. Питання впровадження інноваційних підходів у вищій школі розглядалися у працях В. Андрущенка, І. Дичківської; сутність поняття інновації в освіті висвітлена у працях В. Кременя, А. Кузьмінського, В. Лугового, В. Морозова; проблеми впровадження інноваційних та інформаційних технологій у навчальний процес досліджували А. Блинниковою, М. Власовою, Л. Гапоненко, Т. Коваль, А. Пєхота, А. Пометун, О. Савченко, П. Сауха, Л. Тарасенко; можливості поєднання традиційних та інноваційних методів навчання вивчали Т. Туркот, Д. Чернілевського.

Багато зарубіжних дослідників, вивчаючи інноваційні процеси в освіті, зосередили особливу увагу проблемі інноваційного особистісно-зорієнтованого навчання, пріоритетності розвитку творчої особистості та ії здібностей (Д. Армстронг, Р. Аткінсон, Б. Баун, Б. Блум, Дж. Дьюї, П. Дракер, М. Колкінс, А. Маслоу, Ф. Махлуп, Г. Олпорт, Ч. Паттерсон, Т. Стюарт, А. Тайлер та інші).

Інноваційні тенденції та підходи до вивчення іноземних мов розглянуто у працях В. Дорошенко, С. Ніколаєнко, І. Пододіменко, Т. Решетнік, А. Співаковського, А. Тарнопольського, та інших.

Однак, незважаючи на значні напрацювання з теорії і практики, проблема використання інноваційних методів навчання англійської мови за професійним спрямуванням потребує постійного вивчення та оновлення. Окрім того, існують суперечності, які простежуються:

- між значною кількістю ґрунтовних досліджень з теми та їх практичним застосуванням на заняттях;

- між високими стандартами та вимогами сучасного суспільства до майбутніх фахівців та їхньою неготовністю задовольнити ці вимоги.

Метою статmі є вивчення сутності поняття “інновація у вищій освіті”, визначення характерних особливостей та можливостей використання ефрективних інноваційних методів у процесі навчання іноземної мови за профресійним спрямуванням.

Досягнення цієї мети передбачає виконання низки завдань:

- здійснення аналізу поняття про інновації в освіті;

- з'ясування видів інновацій;

- розгляду можливостей впровадження інноваційних методів навчання у процес вивчення англійської мови за професійним спрямуванням;

- виокремлення найбільш ефективних інноваційних методів навчання англійської мови.

\section{II Матеріал і методи дослідження}

У методологічну основу дослідження покладено аналіз документів, першоджерел, літератури з теми дослідження; методи конкретизації та узагальнення, за допомогою яких виявлено сучасний стан проблеми в умовах розбудови європейського освітнього простору; методи класифікації та систематизації даних для розкриття особливостей добору та структурування інноваційних методів; аналітичний метод, завдяки якому були узагальнені здобуті результати у вигляді висновків і рекомендацій.

Як показав аналіз публікацій, вітчизняні дослідники по-різному розглядають поняття інновації в освіті. Тому вважаємо доцільним перш за все з'ясувати сутність цього поняття і можливості його застосування в освітній ссрері.

у Тлумачному словнику української мови знаходимо наступне визначення терміну: іннова́ція (англ. innovation - нововведення) - ідея, новітній продукт в галузі техніки, технології, організації праці, управління, а також у інших сферах наукової та соціальної діяльності, засноване на використанні досягнень науки і передового досвіду, є кінцевим результатом інноваційної діяльності. 
Вважається, що вперше цей термін було використано у науковому лексиконі в 30-х pp.. XX ст. австрійським дослідником Й. Шумпетером, який стверджував, що необхідно втілювати нововведення та нові технології у процес виробництва, оскільки інновації становлять першооснову розвитку. Первинно цей термін стосувався процесу виробництва та економіки.

Згодом поняття "інновація" набуло універсального значення й почало активно використовуватися по відношеню до наукової та освітянської сфрер. Однак, сутність поняття про інновації постійно змінюється і уточнюється.

Інноваційний процес, на думку І. П. Підласого, може розглядатися і як розвиток трьох основних етапів: генерування ідеї (у певному розумінні - наукове відкриття), розробка ідеї в прикладному аспекті і реалізація нововведення в практиці [1].

Вважаємо, що процес впровадження інновацій (інноваційний процес), який запропонував І. П. Підласий, доцільно доповнити ще двома етапами - випробовування інновацій на практиці та їх корегування; повторний аналіз та оцінка (після корегування) результатів інновацій. На наш погляд, було б коректним стверджувати, що інноваційний процес проходить п'ять етапів (рис. 1).

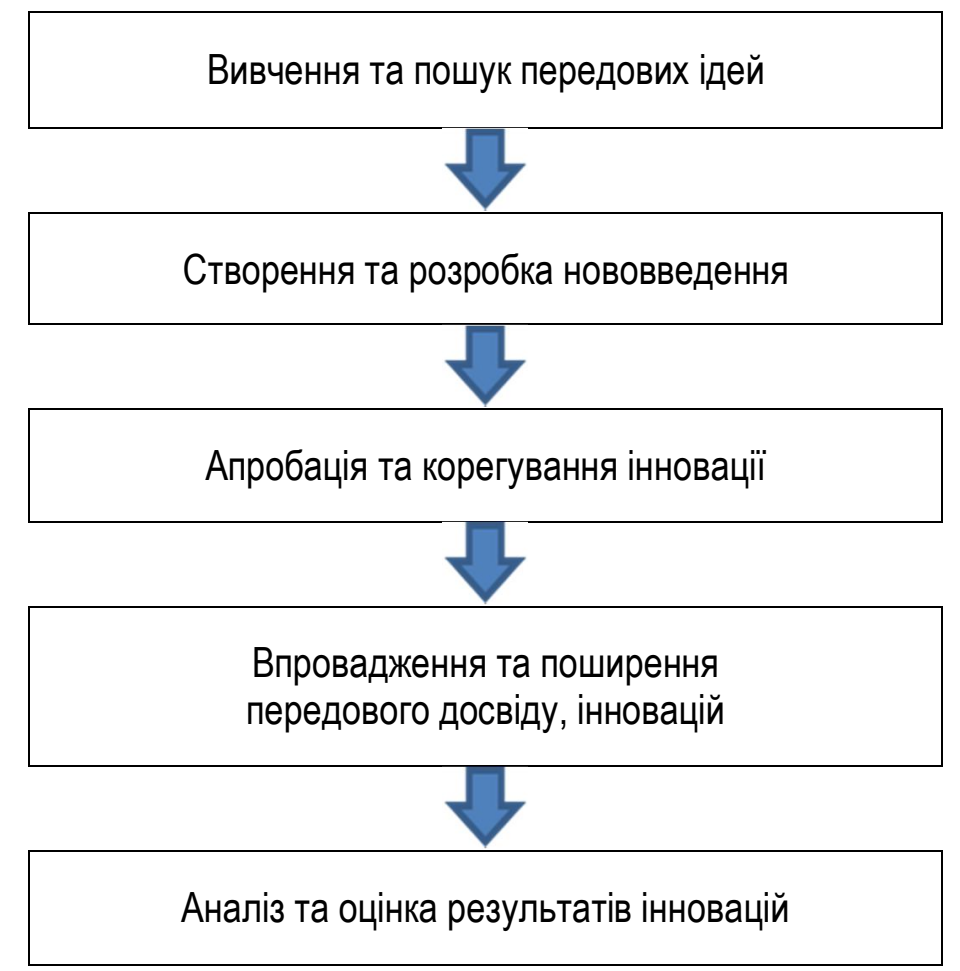

Рис. 1. Етапи впровадження інновацій

Якщо застосувати дане визначення стосовно освітньої сфрери, то у такому випадку можемо вважати, що освітні інновації - це зміни, які спрямовані на постійне покращення існуючої системи та модернізацію змісту та цілей освіти відповідно до сучасних потреб. Враховуючи сказане вище ми погоджуємось із твердженням В.Вакуленко, що "інновація $€$ основною формою розвитку сфрери освіти" [2]. Він також зазначає, що "інновацію в освіті розглядають як реалізоване нововведення - у змісті, методах, прийомах і фрормах навчальної діяльності та вихованні особистості (методиках, технологіях), у змісті і фрормах організації управління освітньою системою, а також в організаційнії структури закладів освіти, у засобах навчання та виховання і в підходах до соціальних послуг в освіті, що суттєво підвищує якість, ефективність та результативність навчально-виховного процесу" [2].

Проаналізувавши існуючі підходи до визначення поняття "інновація" Н.Шарата зазначає, що "у процесі дослідження зазначеного поняття науковці умовно поділилися на дві групи відповідно до ототожнення або розмежування понять "нововведення" та "інновація". Ці категорії мають змістові відмінності щодо результату, який планується досягти. Нововведення охоплює лише декілька етапів інноваційного процесу і може не впроваджуватися у виробництво, тоді як під процесом створення 
інновації розуміють повний цикл від генерації ідеї, створення нововведення і до його впровадження у виробництво. Отже, нововведення - це відповідно оформлений результат фундаментальних та/ або прикладних досліджень, розробок або експериментальних робіт у будь-якій сфері діяльності, здійснених для підвищення ії ефективності та не доведені до масового впровадження. [3].

Дуже часто у дослідженнях зустрічаються терміни "освітні інновації" та "педагогічні інновації" синонімічно. Однак, між "освітою" та "педагогікою" існують відмінності. Під освітою розуміється процес і результат засвоєння особистістю певної системи наукових знань, практичних умінь та навичок. Освіта може бути: початковою, середньою, технічною, професійною, вищою і т.д. Тому, термін "освітні інновації" стосується більше системи освіти та їі складових компонентів, а саме: організаційних, економічних, управлінських, соціальних, педагогічних, культурних, наукових, та психолого-педагогічних аспектів. Педагогіка - наука про майстерність навчати та виховувати підростаючі покоління. Педагогічні інновації "є одним з аспектів освітніх інновацій. Вони охоплюють сферу педагогічного процесу й спрямовані на вирішення відповідних задач. Педагогічний процес $є$ цілеспрямованою системою впливу на суб'єктів освітнього процесу, яка приводить до якісних змін індивіда. Система впливу включає педагогічні технології, педагогічну техніку, а також окремі елементи - форму, засіб, метод, зміст (навчання, виховання, організація, управління)" [4].

Тож, під інноваціями у сфері вищої освіти ми розуміємо створення, реалізацію, апробацію та поширення нових оригінальних ідей, способів, підходів, що відбуваються з урахуванням досягнень науки, освіти, прогресивного педагогічного та управлінського досвіду, які передбачають модернізацію та використання таких високоефективних освітніх технологій, які б сприяли підвищенню якості сучасного навчального процесу.

Закономірно, що інновації в освіті - це пошук і створення нестандартних ідей, які уможливлюють шляхом проб, експериментів, апробацій вирішення тих суперечностей, що існують між традиційною освітою та потребами сучасного суспільства. "Інновації в освіті $є$ закономірним явищем, динамічним за характером і розвивальним за результатами, їх запровадження дозволяє вирішити суперечності між традиційною системою і потребами в якісно новій освіті. Суттєвою ознакою інновації є ії здатність впливати на загальний рівень професійної діяльності педагога, розширювати інноваційне поле освітнього середовища у навчальному закладі, регіоні. Як системне утворення інновація характеризується інтегральними якостями: інноваційний процес, інноваційна діяльність, інноваційний потенціал, інноваційне середовище" [5].

Тому залежно від того, наскільки нагальними є ці потреби, настільки швидко відбуватиметься процес впроваджень інновацій у ссрері освіти. Зокрема, інновації в освіті кінця XX - початку XXI ст. мають за мету вирішити проблеми, пов'язані із поліпшенням якості освіти, корегуванням системи оцінювання якості знань, формуванням у студентів більш практичних умінь та навичок в обраній ними профресійній сфері, подоланням суперечностей між темпами соціально-культурного розвитку та вимогами сучасного суспільства.

\section{III Результати}

Здійснивши аналіз останніх досліджень та публікацій, ми дійшли висновку, що на даний момент немає єдиної класифікації щодо інновацій в освіті. Вважається, що класифрікація інновацій, розроблена відомим російським вченим А. І. Пригожиним, є найбільш універсальною й стосуються, насамперед, сфери виробництва та економіки. Він запропонував розподілити інновації за наступними критеріями: поширеністю, місцем у виробничому циклі, наступністю, за охопленням очікуваної частки ринку, за інноваційним потенціалом та ступенем новизни та за ступенем новизни для ринку.

В. М. Вакуленко, вивчаючи проблему класифікацій інновацій в освіті, зазначає, що їх можна класифікувати за рівнем інноваційної зміни. Далі вона зауважує, що слушними є ідеї дослідників Г. І. Герасимова і Л. В. Ілюхина, які беручи до уваги інтегративний критерій "виокремлюють соціальноосвітню цінність інновації, що містить у собі такі індикатори: ступінь зміни ефективності освітнього та педагогічного процесів з орієнтацією на перспективи суспільного розвитку; професійно-педагогічний і соціальний обсяг перетворень; ступінь професійно-педагогічного та соціального відтворення (широта круга споживачів і швидкість розповсюдження)" [2]. Іншими словами, зміни передбачають вкраплення нових елементів у традиційний підхід до освіти. В останньому випадку учасники інновації, вчителі та 
керівники, реалізують уже наявну педагогічну систему в тісному контексті із зарубіжними колегами, а не будують її наново за західним чи вітчизняним зразком.

У галузі вищої освіти можна виділити такі види інновацій, які $є$ необхідною умовою для конкурентоспроможності вищих навчальних закладів, а саме: інновації в змісті освіти; інновації в педагогічному процесі; інновації в організаційних структурах вищої освіти; інновації в діяльності та відносинах між викладачами і студентами; інновації у сфрері освітніх послуг, розвиток співпраці 3 соціальними партнерами, замовниками кадрів; інновації в галузі міжнародного співробітництва вищих навчальних закладів [4].

Доцільно розглядати два напрями впровадження інноваційної діяльності в освіті:

1) модернізація традиційного навчання у руслі ефективної організації засвоєння заданих зразків, досягнення чітко визначених еталонів. В рамках цього напряму оновлення навчального процесу орієнтоване на традиційні дидактичні завдання репродуктивного навчання, уявлення про навчання як "технологічний" конвеєрний процес 3 чітко фіксованими, детально описаними очікуваними результатами;

2) інноваційний підхід до навчального процесу, в якому основною метою є розвиток у студентів можливостей освоювати новий досвід на основі цілеспрямованого формування творчого і критичного мислення, досвіду та інструментарію навчально-дослідної діяльності, ролевого та імітаційного моделювання [6].

Інновації у вищій школі передбачають: а) створення електронної бази даних про інновації у вищій освіті, організація науково-дослідницьких (фундаментальних і прикладних) та навчально-методичних робіт з проблем професійної освіти; б) вивчення, узагальнення та поширення кращого вітчизняного, європейського та світового досвіду в цій сфері; в) організація і проведення конференцій, семінарів і тренінгових курсів з інноваційних методик викладання гуманітарних та природничо-математичних дисциплін для професійного загалу [7].

Університети, які завжди були і $є$ осередками освіти, науки та просвітництва в Україні, намагаються поєднати вітчизняні традиції, які формувалися упродовж століть у системі вищої школи, із сучасними інноваційними методиками та тенденціями. Зокрема, можна простежити деякі характерні ознаки інноваційної діяльності університетів: спрямування освітньої політики вишів до загальноєвропейських стандартів, особистісно-орієнтоване навчання, упровадження інноваційних методів та технологій навчання, широке використання сучасних інформаційних технологій та мережі Internet, оновлення змісту вищої освіти відповідно до сучасних вимог та запитів суспільства, створення авторських методик, підручників, розвиток багаторівневості в освіті тощо.

Загальновідомим фрактом $є$ те, що традиційна освіта ґрунтується на запам'ятовувані та відтворенні студентами певного обсягу інформації, яку обирає викладач. Такий підхід має авторитарний характер з боку вчителя, а студент виступає у ролі пасивного реципієнта знань. Як результат, студент володіє теоретичними знаннями й відчуває значні труднощі, коли потрібно застосувати свої знання у практичній діяльності. Т.І.Туркот [8] запропонував таблицю із порівняльною характеристикою традиційного та інноваційного навчання (табл. 1).

Враховуючи дані наведені в таблиці, ми робимо висновок про те, що завдяки використанню інноваційних методів навчання у вишах, у студентів з'являється більше можливостей для творчого самовираження та активного пошуку інфрормації, підвищується мотивація студентів до навчання, а набуті ними знання, вміння та навички сприяють їхній готовності вирішувати проблемні ситуації у профресійній діяльності.

Для досягнення визначених цілей використовують різноманітні методи викладання й подачі інформації. Метод викладання як загальнодидактичне поняття можна визначити як "сукупність способів і прийомів спільної діяльності суб'єктів навчального процесу, спрямованої на досягнення освітньої мети, виховання й розвитку особистості”. Будучи універсальними та застосовуючись для викладання різних дисциплін, ці способи взаємодії викладача і студента традиційно диференціюють на методи викладання (показ, пояснення, організація тренування, організація практики, корекція, оцінка) і методи навчання (ознайомлення, осмислення, участь у тренуванні, практика, самооцінка, самоконтроль). Такий розподіл здійснено з урахуванням суб'єкта дії: способи і прийоми діяльності викладача (того, хто викладає) іменують методами викладання; способи і дії того, хто навчається, називають методами навчання [9]. 
У сучасній методиці викладання найбільш прийнятною виявилася класифікація методів, яка побудована на дієвому підході до навчання. Згідно з нею існують наступні групи методів:

а) які забезпечують опанування навчального предмета (словесні, візуальні, практичні, репродуктивні, проблемно-пошукові, індуктивні, дедуктивні);

б) які стимулюють та мотивують навчально-наукову діяльність (навчальні дискусії, проблемні ситуації, ділові ігри, творчі завдання, пошук і дослідження, експерименти, конкурси, вікторини тощо);

3) методи контролю і самоконтролю у навчальній діяльності (опитування, залік, іспит, контрольна робота, тестові завдання, питання для самоконтролю та ін.) [9].

Табл. 1. Порівняльна характеристика традиційного та інноваційного навчання

\begin{tabular}{|c|c|c|}
\hline \multirow{2}{*}{$\begin{array}{c}\text { Критерій } \\
\text { характеристики }\end{array}$} & \multicolumn{2}{|c|}{ Особливості технології навчання } \\
\hline & традиційна & інноваційна \\
\hline $\begin{array}{l}\text { Місце і роль викладача } \\
\text { у навчальному процесі }\end{array}$ & $\begin{array}{l}\text { Суб'єкт, який визначає всі } \\
\text { аспекти процесу навчання }\end{array}$ & $\begin{array}{c}\text { Суб'єкт, який ініціює процес навчання і } \\
\text { стимулює перетворення студентів в активних } \\
\text { суб'єктів процесу навчання }\end{array}$ \\
\hline $\begin{array}{l}\text { Місце і роль студентів у } \\
\text { навчальному процесі }\end{array}$ & $\begin{array}{c}\text { Сприйняття, засвоєння і } \\
\text { відтворення інформації, яку } \\
\text { надає викладач }\end{array}$ & $\begin{array}{c}\text { Активне засвоєння і генерування знань, } \\
\text { отриманих із різноманітних джерел }\end{array}$ \\
\hline $\begin{array}{l}\text { Тип інфоромаційної } \\
\text { комунікації }\end{array}$ & $\begin{array}{c}\text { Керована викладачем } \\
\text { інфрормація }\end{array}$ & $\begin{array}{c}\text { Багатоканальна система, яка генерує } \\
\text { інфрормацію між викладачем і студентами, а } \\
\text { також забезпечує інформаційну взаємодію } \\
\text { між ними }\end{array}$ \\
\hline $\begin{array}{l}\text { Методи управління } \\
\text { процесом навчання }\end{array}$ & $\begin{array}{c}\text { Тоталітарне або авторитарне } \\
\text { управління }\end{array}$ & Демократичне управління \\
\hline Рівень творчості & $\begin{array}{c}\text { Творчість притаманна } \\
\text { викладачеві, студенту } \\
\text { пропонується вже готова } \\
\text { інфрормація }\end{array}$ & $\begin{array}{c}\text { Творчість викладача стає все більш } \\
\text { різноманітною, а діяльність студентів має } \\
\text { яскраво виражений творчий характер }\end{array}$ \\
\hline $\begin{array}{c}\text { Проблемність процесу } \\
\text { навчання }\end{array}$ & $\begin{array}{c}\text { У кращому випадку має місце } \\
\text { описування проблем чи } \\
\text { проблемних ситуацій }\end{array}$ & $\begin{array}{c}\text { Навчання відбувається в основному на } \\
\text { прикладах і в умовах проблемних ситуацій, } \\
\text { що сприяє фрормуванню вмінь їх визначення і } \\
\text { вирішення }\end{array}$ \\
\hline $\begin{array}{l}\text { Рівень контролю за } \\
\text { процесом навчання }\end{array}$ & $\begin{array}{c}\text { Формальні, не індивідуалізовані } \\
\text { форми контролю. Жорсткий } \\
\text { контроль }\end{array}$ & $\begin{array}{c}\text { Гнучкі індивідуалізовані форми контролю, } \\
\text { навчання студентів самоконтролю та } \\
\text { рефрлексії }\end{array}$ \\
\hline Результат навчання & Сукупність знань & $\begin{array}{c}\text { Сукупність знань, практичних вмінь і навичок, } \\
\text { здатність до їх творчого використання в } \\
\text { професійній діяльності }\end{array}$ \\
\hline
\end{tabular}


Отже, інноваційні методи навчання - це "усі ті нові й ефективні способи навчання (здобуття, передачі й продукування знань), які сприяють інтенсифікації та модернізації навчального процесу, розвивають творчий підхід і особистісний потенціал його учасників" [4].

Найбільш прийнятною для навчання англійської мови за професійним спрямуванням видається класифікація методів за способом взаємодії викладача й студентів на заняттях, обґрунтована О. М. Біляєвим, на яку посилається У. В. Науменко [10]. Вона передбачає такі способи взаємодії як:

1. Викладач викладає мовний матеріал - студенти слухають (розповідь, пояснення).

2. Студенти й викладач обмінюються думками з питань, що вивчалися на заняттях з англійської мови, завдяки чому доходять потрібних висновків, узагальнень, формулюють визначення, правила.

3. Викладач організовує спостереження студентів над фактами, що вивчаються і явищами мови 3 подальшим колективним обговоренням його результатів.

4. Студенти під керівництвом викладача самостійно добувають знання з мови за підручником.

5. Студенти шляхом виконання практичних завдань і вправ набувають потрібні знання. Виходячи з цього, виділяють відповідні методи навчання мови у вищій школі [10].

\section{IV Обговорення}

У сфері викладання англійської мови методи навчання постійно розвиваються й змінюються разом з тим, як змінюються інформаційні технології й сучасне суспільство. Нині не можливо уявити навчально-виховний процес у вищих освітніх закладах без використання інформаційно-технічних технологій, які лежать в основі накопичення, оброблення, представлення і використання інформації за допомогою електронних засобів.

Викладач іноземної мови повинен вміти знаходити автентичний матеріал на певну тематику у пошукових сайтах, адаптовувати його під потреби та можливості студентів, користуватися мультимедійними програмами, підручниками, створювати власні web-сторінки, блоги, тощо [11, 12]. Використання комп'ютерних IT забезпечує інтерактивність навчання, яке відбувається за рахунок прямого та зворотного зв'язку з тими, хто навчається, під час виконання вправ, практичних заннять, творчих проектів [13]. Враховуючи те, що студенти самі визначають темп роботи, відкривається можливість здійснення індивідуального навчання для кожного бажаючого [14].

Існує ряд освітніх сайтів та інструментів, які стануть в нагоді як учителям шкіл, так і викладачам вишів при плануванні та підготовці до занять. Зокрема, це: Edmodo (альтернатива Moodle), EduBlogs (пропонує надійне і безпечне місце для ведення блогів), Sуре (співпраця та навчання у режимі онлайн), Wikispaces (дозволяє вчителю поділитися онлайн зі своїми учнями уроками, медіа та іншими матеріалам), Quora (можна використовувати для співпраці і спілкування з іншими професіоналами даної ссрери), StudySync (містить повнофункціональний інструментарій для викладання та навчання, включаючи цифрову бібліотеку, щотижневі публікації практичного призначення, онлайн-твори і експертні оцінки, базові завдання і мультимедійні уроки), Teachers Pay Teachers (сайт для обміну інфрормацією серед учителів-колег), Capzles (містить додатки із навчальними матеріалами, мультимедіа, фото, відео, документи), Prezi (можливість створювати презентації), Wordle (можливість створювати хмари слів з метою удосконалення лексичного запасу), Quizlet (полегшує педагогам процес створення навчальних карток, посібників), YouTube (налічує безліч навчальних матеріалів), AudioBoo (можливість записувати аудіо) та інші [15].

Ще одним із найпоширеніших засобів навчання є електронні підручники, які можуть містити тестові завдання, презентації, відеоматеріали, документальні й художні фільми, які викладач вибирає відповідно до певної теми заняття [16]. Під час виконання практичних завдань студенти можуть використовувати мультимедійні програмами, електронні та он-лайн словники ("Lingvo", "Multitran”, "McMillian On-Line Dictionary", тощо) або мультимедійні довідники й енциклопедії. Важливим доповненням, який збільшить ефективність навчання студентів, буде використання інтерактивної дошки та мультимедійного проектора. Завдяки цим засобам наочності значно підвищиться активність студентів на заняттях, пришвидшиться темп засвоєння інформації.

Задля розвитку іншомовних комунікативних навичок з фаху й посилення мотивації студентів до вивчення англійської мови за професійним спрямуванням можна використовувати й такі інтерактивні 
форми роботи, як: кейс-технології, круглий стіл, читання зигзагом (jigsaw reading), дебати, ділові ігри, метод кейсів, тренінги, відео конференції, мозковий штурм $[17,18]$.

Однією із найвідоміших інтерактивних методик, яка набула популярності в Великобританії, США, Німеччині, Данії та інших країнах став кейс-метод (case study), який вперше був застосований у 1910 р. у Гарвардській бізнес-школі, яка відомій своїми інноваціями. В Україні вона набула поширення лише у кінці XX ст. Сутність методу полягає у використанні конкретних випадків (ситуацій, історій, текстів, які називаються "кейсом") для спільного аналізу, обговорення та вироблення рішень студентами з певного розділу навчальної дисципліни [19]. На нашу думку, цей метод $є$ ефрективним у сучасній методиці викладання іноземної мови за професійним спрямуванням так як спонукає студентів активно спілкуватися, обговорюючи реальні ситуації/ проблеми, будувати запитання та формулювати відповіді, реагувати на висловлювання інших, дискутувати у парах чи групах. Вирішуючи ситуацію, студенти не лише розвивають спонтанне мовлення, але й вчаться прислухатися до думки інших, співпрацювати у колективі. Прикладом представлення кейсу для студентів може бути текст, таблиця, діаграма, яка вимагає вирішення певної проблеми. Окрім того, влучно обраний матеріал для кейс-методу із певним професійним орієнтуванням дозволяє наблизити навчальний процес до реальних умов (наприклад, створення фррагменту сцени переговорів, укладання договорів).

Інший метод, який оптимізує навчальний процес й сприяє активізації інтелектуальної діяльності студентів є "мозкова атака" (brainstorming). Його запропонував американський винахідник А.Осборн. На заняттях англійської мови метод "мозкової атаки" варто застосовувати на етапі вивчення або закріплення нової лексики. Він передбачає виокремлення проблеми, висування різних ідей щодо їі вирішення та критичного аналізу цих ідей, зважування усіх "за" та "проти" й прийняття остаточного рішення [20].

Метод синектики (англ. синектика - "суміщення різнорідних елементів"), автором якого вважають американського вченого В. Дж. Гордона, є методом стимулювання творчої діяльністі студентів у процесі вивчення англійської мови за професійним спрямуванням. В його основу покладено принцип "мозкової атаки" та принцип використання порівнянь та аналогій. Однак, на відміну від "мозкової атаки", У. Гордон запропонував принципово нові підходи: створення постійного складу групи (5-7 осіб) для дослідження певної проблеми, учасники якої мають різне захопленнями чи $є$ фрахівцями різного просрілю, що дозволяє вирішити поставлену проблему враховуючи різні точки зору; застосування образних порівнянь та аналогій під час створення ідей при відборі кінцевого варіанту.

Метод дискусії, "круглого стола", "засідання експертної групи", конференції, форуму або дебатів доцільно використовувати на заняттях англійської мови за професійним спрямуванням на підсумковому етапі, коли відбувається закріплення та удосконалення мовленнєвих навичок студентів. Студенти повинні бути готові використати вивчений матеріал з тим, щоб обговорити проблему, аргументувати свою позиції та висловити власне схвальне/ несхвальне рішення, дискутувати, відстоювати вісловлену позицію.

Використання методу рольової гри як інноваційного є також цікавою формою роботи у ході якої студенти повинні виконати певні ролі та завдання. Рольові ігри максимально наближають учасників до реальних умов і дають їм можливість відчути себе професіоналом в обраній сфері. Наприклад, студенти, які обрали професію у сфері обслуговування або туризму, можуть "зіграти" сцену бронювання готелю, або спробувати себе у ролі екскурсовода, офріціанта тощо.

Метод проектів, який був запропонований американським педагогом У. Кілпатріком на початку XX ст., передбачає виконання певного практичного завдання індивідуально чи у парі. Студенти можуть здійснювати пошукову або дослідницьку роботу, беруть інтерв'ю, проводять опитування, роблять фото чи відео, щоб в подальшому презентувати свої знахідки у формі презентації, доповіді чи письмової роботи. Цей метод вимагає творчого підходу й розвиває навички самостійної та пошукової роботи у студентів. Завдання педагога - консультувати та корегувати роботу студентів.

Ще одним ефективим методом навчання англійської мови за професійним спрямуванням $є$ використання інтерактивних ігор. В методиці навчання все частіше почали використовувати термін “гейміфікація" (або ігрофікація, від англ. "gamification",геймізація), який широко застосовується у процесі навчання іноземних мов, що перетворює її вивчення у приємний, захоплюючий процес. Використання ігор сприяє розвиткові та удосконаленню навичок студентів з граматики, лексики, говоріння та умінь 
будувати висловлювання як для монологічного, так і для діалогічного мовлення. Беручи до уваги власний досвід викладання, можна з впевненістю сказати, що ігри активізують навчальну діяльність студентів, підвищуючи їхній інтерес до вивчення мови, стимулюють позитивні емоції. Для прикладу можна запропонувати для студентів гру у формі квесту (від англ. quest - пошук, пошуки пригод). Це така інтелектуальна гра-змагання, яка вимагає послідовного виконання заздалегідь підготовлених завдань у формі загадок командами або окремими гравцями.

\section{V Висновки}

3 кожним роком необхідність володіння іноземною мовою зростає. Англійська мова закріплює свою позицію як світова лінгва франка (the world's lingua franca). Багато вітчизняних студентів вивчають іï для того, щоб вільно спілкування у галузях бізнесу, торгівлі, освіти та туризму. Використання інноваційних методів та технологій навчання у сфері вищої професійної освіти, яка готує професійні та наукові кадри для всіх галузей промисловості та сфер життя людини, є одним із шляхів, що дозволяє оптимізувати та модернізувати процес навчання. Саме тому, необхідно постійно здійснювати пошук нових ефективних методів навчання і вивчення англійської мови оскільки методика навчання іноземної мови змінюється й розвивається разом із тим, як змінюються інформаційні технології й сучасне суспільство. Завдяки використанню інноваційних методів навчання у вишах, у студентів з'являється більше можливостей для творчого самовираження та активного пошуку й використання інформації, підвищується їх мотивація до навчання, а набуті ними знання, вміння та навички сприяють формуванню готовності вирішувати проблемні ситуації у професійній діяльності.

\section{Бібліографрічні посилання}

1. Підласий І. Педагогічні інновації / Рідна школа. 1998. №12. С. 3-17.

2. Вакуленко В. М. Види інновацій в освіті та їх класифікація / Вісник Національної академії Державної прикордонної служби України. 2010. Вип. 4. URL: http://nbuv.gov.ua/UJRN/Vnadps_2010_4_4 (дата звернення 25.07.2019).

3. Шарата Н. Г. Інноваційність в освіті - ознака сучасності / Вісник Чернігівського нац. пед. ун-ту. Сер.: Педагогічні науки. 2012. Вип. 97. С. 158-160.

4. Буркова Л. В. Класифікація інновацій в освіті / Теорія і методика управління освітою: Електронне наукове фахове видання. Вип. 4. Київ. 2010. С. 18-24.

5. Дубасенюк О. А. Інноваційні освітні технології та методики в системі професійно-педагогічної підготовки. Професійна педагогічна освіта: інноваційні технології та методики: монографія / за ред. О. А. Дубасенюк. Житомир : Вид-во ЖДУ ім. І. Франка, 2009. С. 14-47.

6. Старицька О. П. Важливість інноваційного розвитку вищої освіти при інтеграції в європейське освітнє співтовариство / Інноваційна економіка: всеукр. наук.-виробн. журнал. 2012. № 1. С. 32.

7. І Інновації у вищій освіті: проблеми, досвід, перспективи : монографія / за ред. П. Ю. Сауха. Житомир : Вид-во ЖДУ ім. Івана Франка, 2011. 444 с.

8. Туркот Т. І. Педагогіка вищої школи : навч. посіб. Херсон, 2011. 608 с.

9. Артикуца Н. В. Інноваційні методики викладання дисциплін у вищій юридичній освіті / матеріали Міжнародної науково -методичної конференції, присвяченої 390-річчю з дня заснування Київської братської школи-предтечі КиєвоМогилянської академії, 25-28 травня 2005 року. Київ, 2005. С. 3-25.

10. Науменко У. В. Інноваційні методи навчання англійської мови у вищій школі в умовах модернізації / Молодий вчений. 2018. №3.1 (55.1). C.118-122.

11. Vitthal V. Parab. Innovative Techniques, Methods and Trends in English Language Teaching / Journal Of Humanities And Social Science. 2015. Vol 20. Issue 6. PP.40-44.

12. Cook V. Second Language Learning and Language Teaching. New York: Routledge. 2016. 344 p.

13. Rani N., Hapawat A., Indira Devi V. Applying Innovative Teaching Methods In Teaching English As A Second Language/ International Journal of Scientific Research and Review. 2019. Volume 07 . Issue $03 . \quad$ URL: http://ijsrr.co.in/images/full_pdf/1553413658_C803.pdf (дата звернення 20.08.2019).

14. Гуревич Р. С. Інформаційні технології навчання: інноваційний підхід : навчальний посібник. Вінниця : ТОВ фірма «Планер», 2012. 348 c.

15. Anburaj G., Christopher G., Ms. Ni Ming. Innovative Methods of Teaching English Language/ Journal Of Humanities And Social Science. Volume 19. Issue 8. Ver. IV (Aug. 2014), P. 62-65. URL: http://www.iosrjournals.org/iosr-jhss/papers/Vol19issue8/Version-4/M019846265.pdf (дата звернення 20.08.2019)

16. Ghritchenko I., Nesterenko I. Innovative Approaches To Teaching English Language To Artists/ Advanced Education. 2016. Issue 6. P.106-110. URL: file://Users/mac/Downloads/85954-186072-1-PB\%20(1).pdf (дата звернення 20.08.2019) 
17. Saliu B., Hajulla H. Best Practices in the English for Specific Purpose Classes at the Language Center. URL: https://www.sciencedirect.com/science/article/pii/S1877042816313349 (дата звернення 20.08.2019)

18. Чонг К. С. 10 інновацій, які змінили викладання анелійської мови : матеріали сайту British Council. URL: http://www.dut.edu.ua/ua/news-1-525-5953-desyat-innovaciy-yaki-zminili-vikladannya-angliyskoi-movi-chastina-3 (дата звернення 25.07.2019).

19. Ефендієва С. М. Упровадження інновацій у практику викладання англійської мови у вищих навчальних закладах. Удосконалення якості підготовки лікарів у сучасних умовах : матеріали науково-практичної конференції 3 міжнародною участю. Полтава, 2016. С. 75-76.

20. Unin N. Brainstorming as a Way to Approach Student-centered Learning in the ESL Classroom/ Social and Behavioral Sciences.2016. URL: https://www.researchgate.net/ publication/305394171_Brainstorming_as_a_Way _to_Approach_ Student-centered_Learning_in_the_ESL_Classroom

\section{References}

1. Pidlasyi, I. (1998). Pedahohichni innovacii. Ridna shkola, 12, 3-17. [in Ukrainian]

2. Vakulenko, V. M. (2010). Vydy innovacij v osviti ta yikh klasyfikaciia. Visnyk Natsionalnoi akademii Derzhavnoi prykordonnyi sluzhby Ukrayiny, 4. URL: http://nbuv.gov.ua/UJRN/Vnadps_2010_4_4 (accessed 25.07.2019). [in Ukrainian]

3. Sharata, N. G. (2012). Innovaciinist v osviti - oznaka suchasnosti. Visnyk Chernihivskogo natsionalnoho ped. un-tu., Ser.: Pedahohichni nauky, 97, 158-160. [in Ukrainian]

4. Burkova, L. V. (2010). Klasyfikatsiia innovacii v osviti. Teoriia i metodyka upravlinnia osvitoiu: Elektronne naukove fakhove vydannia, 4, 18-24. [in Ukrainian]

5. Dubaseniuk, O .A. (Ed.) (2009). Innovaciini osvitni tekhnolohii ta metodyky v systemi profesino-pedahohichnoi pidhotovky. Profesiina pedahohichna osvita: innovaciini tekhnolohii ta metodyky: monografiia. Vyd-vo ZhDU im. I. Franka, Zhytomyr, Ukraine. [in Ukrainian]

6. Starytska, O. P. (2012). Vazhlyvist innovaciinoho rozvytku vyshchoi osvity pry intehracii $v$ yevropeiske osvitnie spivtovarystvo. Innovaciina ekonomika: Vseukr. nauk.-vyrobn. Zhurnal, 1, 32. [in Ukrainian]

7. Sauh, P. Yu. (Ed.) (2011). Innovacii u vyshchii osviti: problemy, dosvid, perspektyvy : monografiia. Vyd-vo ZhDU im. Ivana Franka, Zhytomyr, Ukraine. [in Ukrainian]

8. Turkot, T. I. (2011). Pedahohika vyshchoi shkoly: navch. posib.: rekom. MON Ukrainy dlia studentiv mahistratury vyshchykh navchalnykh zakladiv nepedahohichnogo profiliu. Kherson, Ukraine. [in Ukrainian]

9. Artykutsa, N. V. (2005). Innovaciini metodyky vykladannia dystsyplin u vyshchii yurydychnii osviti. Materialy Mizhnarodnoi naukovo-metodychnoi konferentsii, prysviachenoi 390-richchiu z dnia zasnuvannia Kyivskoi bratskoi shkoly-predtechi Kyievo-Mohylianskoi akademii, 25-28 travnia 2005 roku, vidp. red. N. V. Artykucza; NaUKMA, f-t pravnychykh nauk, Tsentr innovaciinykh metodyk, 3-25. [in Ukrainian]

10. Naumenko, U. V. (2018). Innovaciini metody navchannia angliiskoi movy u vyshchii shkoli v umovakh modernizacii. Molodyi vchenyi, 3.1 (55.1), 118-122 [in Ukrainian].

11. Vitthal, V. Parab. (2015). Innovative Techniques, Methods and Trends in English Language Teaching / Journal Of Humanities And Social Science, 20(6), 40-44.

12. Cook, V. (2016). Second Language Learning and Language Teaching. Routledge, New York, USA, 344.

13. Rani, N., Hapawat, A., Indira, Devi V. (2019). Applying Innovative Teaching Methods In Teaching English As A Second Language. International Journal of Scientific Research and Review, 07(03). URL: http://ijsrr.co.in/images/full_pdf/1553413658_C803.pdf (accessed 20.08.2019).

14. Gurevych, R. S. (2012). Informaciini tekhnolohii navchannia: innovatsiinyi pidkhid : navchalnyi posibnyk. TOV firma «Planer», Vinnytsia, Ukraine. [in Ukrainian]

15. Anburaj, G., Christopher, G., Ms. Ni Ming. (2014). Innovative Methods of Teaching English Language. Journal Of Humanities And Social Science, 19(8), ver. IV, 62-65. URL: http://www.iosrjournals.org/iosr-jhss/papers/Vol19-issue8/Version-4/ M019846265.pdf (accessed 20.08.2019).

16. Ghritchenko, I., Nesterenko, I. (2016). Innovative Approaches To Teaching English Language To Artists. Advanced Education, 6. 106-110. URL: file:///Users/mac/Downloads/85954-186072-1-PB\%20(1).pdf (accessed 20.08.2019).

17. Saliu, B., Hajrulla, H. (2016). Best Practices in the English for Specific Purpose Classes at the Language Center. ProcediaSocial and Behavioral Sciences, 232, 745-749. URL: https://www.sciencedirect.com/ science/ article/pii/ S1877042816313349 (accessed 20.08.2019).

18. Chong, K. S. (2008). 10 innovacii, yaki zminyly vykladannia angliiskoi movy: materialy saitu British Council. URL: http://www.dut.edu.ua/ua/news-1-525-5953-desyat-innovaciy-yaki-zminili- vikladannya-angliyskoi-movi-chastina-3 (accessed 25.07.2019). [in Ukrainian]

19. Efendiyeva, S. M. (2016). Uprovadzhennia innovatsii u praktyku vykladannia anhliiskoi movy u vyshchykh navchalnykh zakladakh. Udoskonalennya yakosti pidgotovky likariv u suchasnykh umovakh : materialy naukovo-praktychnoi konferentsii z mizhnarodnoiu uchastiu, Poltava, 75-76. [in Ukrainian]

20. Unin N. (2016). Brainstorming as a Way to Approach Student-centered Learning in the ESL Classroom. Social and Behavioral Sciences. URL: https://www.researchgate.net/ publication/305394171_ Brainstorming_as_ a_Way_to_ Approach_Student-centered_Learning_in_the_ESL_Classroom (accessed 20.08.2019). 


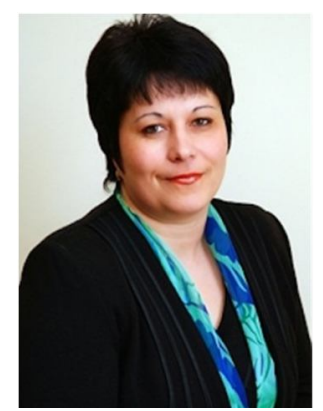

\section{Заблоцька Любов Михайлівна.}

Кандидат педагогічних наук, доцент, доцент касредри іноземних мов,

Тернопільський національний педагогічний університет імені Володимира Гнатюка,

вул. Максима Кривоноса, м. Тернопіль, Україна, 46027.

E-mail: lubazab@ukr.net

\section{Zablotska Liubov Mykhailivna.}

Cand.Sc. (Pedagogical), Associate Professor, Associate Professor of Foreign Language Department,

Ternopil Volodymyr Hnatiuk National Pedagogical University,

Vul. Maksyma Kryvonosa, 2, Ternopil, Ukraine, 46027.

E-mail: lubazab@ukr.net

\section{ORCID: https://orcid.org/0000-0002-4388-4710}

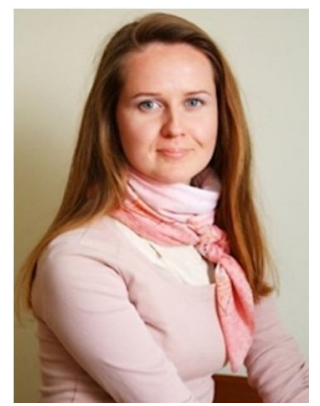

\section{Мелещенко Віра Олександрівна.}

Кандидат філологічних наук, викладач кафедри іноземних мов,

Тернопільський національний педагогічний університет імені Володимира Гнатюка,

вул. Максима Кривоноса, м. Тернопіль, Україна, 46027.

E-mail: vira.burko@gmail.com

\section{Meleshchenko Vira Oleksandrivna.}

Cand.Sc. (Philological), Lecturer of Foreign Language Department,

Ternopil Volodymyr Hnatiuk National Pedagogical University,

Vul. Maksyma Kryvonosa, 2, Ternopil, Ukraine, 46027.

E-mail: vira.burko@gmail.com

ORCID: https://orcid.org/0000-0002-3484-9905

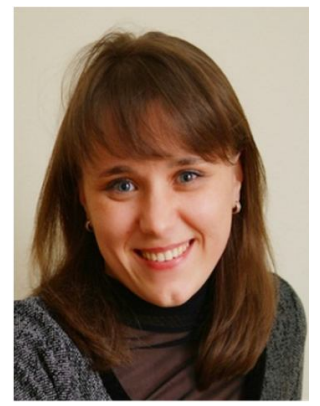

Черній Людмила Віталіївна.

Кандидат педагогічних наук, викладач кафедри іноземних мов,

Тернопільський національний педагогічний університет імені Володимира Гнатюка,

вул. Максима Кривоноса, м. Тернопіль, Україна, 46027.

E-mail: Iyuda.chernii@gmail.com

\section{Chernii Liudmyla Vitaliivna.}

Cand.Sc. (Pedagogical), Lecturer of Foreign Language Department,

Ternopil Volodymyr Hnatiuk National Pedagogical University,

Vul. Maksyma Kryvonosa, 2, Ternopil, Ukraine, 46027.

E-mail: lyuda.chernii@gmail.com

ORCID: https://orcid.org/0000-0002-4755-9536

\section{Citation (APA):}

Zablotska, L., Meleshchenko, V., Chernii, L. (2019). Innovative methods of teaching English for specific purposes at higher educational institutions. Engineering and Educational Technologies, 7 (3), 85-96. doi: https://doi.org/10.30929/2307-

9770.2019.07.03.08

\section{Цитування (ДСТУ 8302:2015):}

Заблоцька Л. М., Мелещенко В. О., Черній Л. В. Інноваційні методи навчання англійської мови за професійним спрямуванням у закладах вищої освіти / Інженерні та освітні технології. 2019. Т. 7. № 3. С. 85-96. doi: https://doi.org/10.30929/23079770.2019 .07 .03 .08

Обсяг статmі: сторінок-12 ; умовних друк. аркушів - 1,738. 